\title{
CONTAMINATION OF THE ROOT VEGETABLES WASH WATER AND ITS TREATMENT EFFICIENCY
}

Midona DAPKIENE், dr., assoc. prof. at the Institute of Hydraulic Engineering, Aleksandras Stulginskis University. Address: Universiteto g. 10, LT-53361 Kaunas-Akademija, Kaunas district., midona.dapkiene@ asu.lt (corresponding author)

Nomeda SABIENE், dr., junior researcher at the Institute of Environment and Ecology, Aleksandras Stulginskis University. Address: Studetu str. 15A-311, LT-53361 Kaunas-Akademija, Kaunas district. nomeda.sabiene@asu.lt

Algirdas RADZEVIČIUS, dr., assoc. prof., head of the Institute of Hydraulic Engineering, Aleksandras Stulginskis University. Address: Universiteto g. 10, LT-53361 Kaunas-Akademija, Kaunas district. algirdas.radzevicius@asu.lt

Growing volume of washed vegetables in Europe and Lithuania means that more drinking water is consumed and more wastewater is produced. Farmers, who engage in washing vegetables, face the problems of wastewater treatment, wastewater storage and utilization. Wastewater released to the environment from their farms would meet hygiene and environmental protection criteria. The aim of the study was to assess the contamination of the root vegetable wash water and to evaluate the possiblity of cleaning of wastewater in the land-based treatment system consisting of one constructed wetland and two biological ponds. The contamination of wastewater, produced by washed root vegetables, in Lithuanian farms was measured according to suspended solids (SS), biochemical oxygen demand (BOD), chemical oxygen demand (COD), total nitrogen and total phosphorus. Pollution of the wash water and wastewater was evaluated comparing the mean values with legislative limit values and with typical sewage contamination values. In all farms wastewater of initial root vegetables washing was treated in settling basins. Wastewater of one carrots washing farm was treated in the land-based wastewater treatment system consisting of surface flow constructed wetland and two biological ponds. Efficiency of the wastewater treatment in this system was according to suspended solids $90 \%, \mathrm{BOD}_{7}-97 \%, \mathrm{COD}_{\mathrm{Cr}}-92 \%$, total nitrogen $-98 \%$, total phosphorus $-97 \%$. The result shows, that the natural wastewater treatment system is suitable for farms, that wash and produce vegetables, but before releasing wastewater to the environment, it has to be settled.

Keywords: root vegetables, treatment efficiency, wash water.

\section{INTRODUCTION}

Increasing supply of the washed and ,ready to eat“" vegetables to the market causes issues of the huge volumes of fresh water used and large quantities of wastewater generated in the processing that requires special treatmen for the vegetable producers. For washing of different kinds of vegetables $2.4-11 \mathrm{~m}^{3} \mathrm{t}^{-1}$ of water is used (Olmez, 2013). Finnish researchers report lower quantities. In their tested facilities, 1.5 to $5 \mathrm{~m}^{3}$ of water was consumed for 1 tonne of finished product. Total water consumption was higher in plants where the vegetables were completely treated and lower, where washing and packaging were carried out (Lehto et al., 2014).

Wash water of the root vegetable contains soil particles, peels and other organic materials, also pesticide residues and pathogenic microorganizms (Mebalds, Hamilton, 2002; Kirby et al., 2003; Henze, Comeau, 2008; Olaimat, Holley, 2012; Alohali, 2015). Commonly the root vegetables washing process consists from several steps (Fig. 1). The first step is dry removal of soil which efficiently reduces amounts of soil particles in the washwater wastes. The initial washing usually is performed in a batch tank. Polishing stage usuallly is aplied for futher cleaning of the root vegetables in order to remove soil residuals and the upper skin if it is neccessary. The last step before packaging is a final wash. In this step clean potable water always is used in order to ensure food safety. The reuse of wash water waste from later step could be applied for the initial first wash step after appropriate treatment when reducing chemical and microbiological contamination to the appropriate level (Rozema, 2016; Mebalds, Hamilton, 2002).

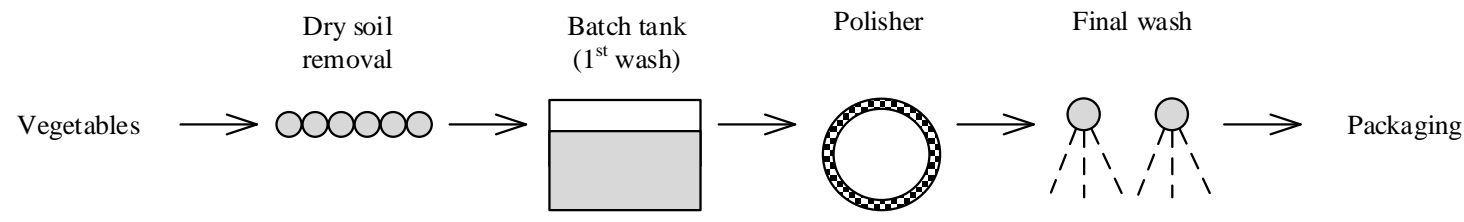

Figure1. Principle flowchart of root vegetable washing process (HMGA Water Project, 2015)

Copyright (C) 2017 The Authors. Published by Aleksandras Stulginskis University. This is an open-access article distributed under the terms of the Creative Commons Attribution License (CC-BY 4.0), which permits unrestricted use, distribution, and reproduction in any medium, provided the original author and source are credited. 
There does not exist the only one efficient method in washwater wastes treatment as it depends on various factors, such as step of the waste water treatment process, futher usage of washwater wastes or discharge waste water to the natural water bodies, also soil texture and amount, contamination level of wastes and their composition.

Settling can reduce suspended solids amounts up to $80 \%$. Results of studies showed that settling (solid removal) was effective only for vegetables washwater waste what contained big amount of coarse particles of sand, peels and other large particles of the organic mater, but was ineffective for waste water containing colloidal particles, clay and dissolved solids. Coagulation and flocculation can significantly increase removal efficiency of the colloidal particles and solids from various wash water. Dissolved air flotation could be floating materials such as charged organic materials removal from the wash water (Zytner, Warriner, 2016).

Usually vegetables producing farms are located in rural areas, natural treatment technologies such as constructed wetlands $(\mathrm{CW})$, biological ponds are suitable for treatment of its wash water. Land-based treatment systems are relatively inexpensive and low-maintenance option to compare with technical treatment systems. Also operation of such systems is low-cost. Their are used widely in agricultural manufacture, such as wastewater from dairy milk houses (VanderZaag et al., 2010; Wood et al., 2015; Rozema et al., 2016), piggeries (Stone et al, 2004; Poach et al., 2004). Bosak et al. (2015, 2016a, 2016b) reported on the performance of different types of land-based systems for treatment of potato farm wash water. Navaro et al. (2013), Puchlik (2016) analysed the treatment of wastewater of fruit and vegetable processing in constructed wetlands. Soroko $(2003,2007,2011)$ investigated efficiency of treatment of wastewater from small fruit and vegetable processing plants in $\mathrm{CW}$.

After demand for washed vegetables arose in Lithuania, farms that wanted to realise their production and remain competitive had to install vegetable washing systems. Growing volume of washed vegetables means that more drinking water is consumed and more wastewater is produced. Farmers who engage in washing vegetables face the problems of wastewater treatment, wastewater storage and utilization. Vegetable washing and processing farms in Lithuania are mostly located in the non-urbanized areas without any access to sewerage and sewage treatment plants. Many farms that wash root vegetables produce insufficiantly treated and requiring the more efficient treatment wastewater, which is spread out on the fields in warm period, but is discharged into the surface waters in cold period.

The aim of the study was to assess the contamination of the root vegetable wash water and to evaluate the efficiency of the land-based treatment system of constructed wetland and biological ponds.

\section{OBJECT DESCRIPTION}

The four large farms that washed root vegetables such as carrots and beetroots were chosen in different areas of Lithuania. These farms use semi-recycled wash water systems as used wash water is transfered to the settling pond or settling tank. Settled in the pond (tank) wash water continues to be used for the $1^{\text {st }}$ wash and at the first step of the polishing. The potable water is used for the final wash of vegetables (Fig. 2). As a certain amount of excess water is consistently generated, it is stored in the pond and spread out on the fields in warm period.

For washing of root vegetables at the $1^{\text {st }}$ stage recirculating water from settling pond was used: $22 \mathrm{~m}^{3} \mathrm{t}^{-1}$ for beetroots, $70 \mathrm{~m}^{3} \mathrm{t}^{-1}$ for carrots and as well as $10 \mathrm{~m}^{3} \mathrm{t}^{-1}$ for carrots from settling tank. For the $2^{\text {nd }}$ wash - drinking water from wells was consumed $\left(4 \mathrm{~m}^{3} \mathrm{t}^{-1}, 7 \mathrm{~m}^{3} \mathrm{t}^{-1}\right.$ and $2 \mathrm{~m}^{3} \mathrm{t}^{-1}$ respectively).

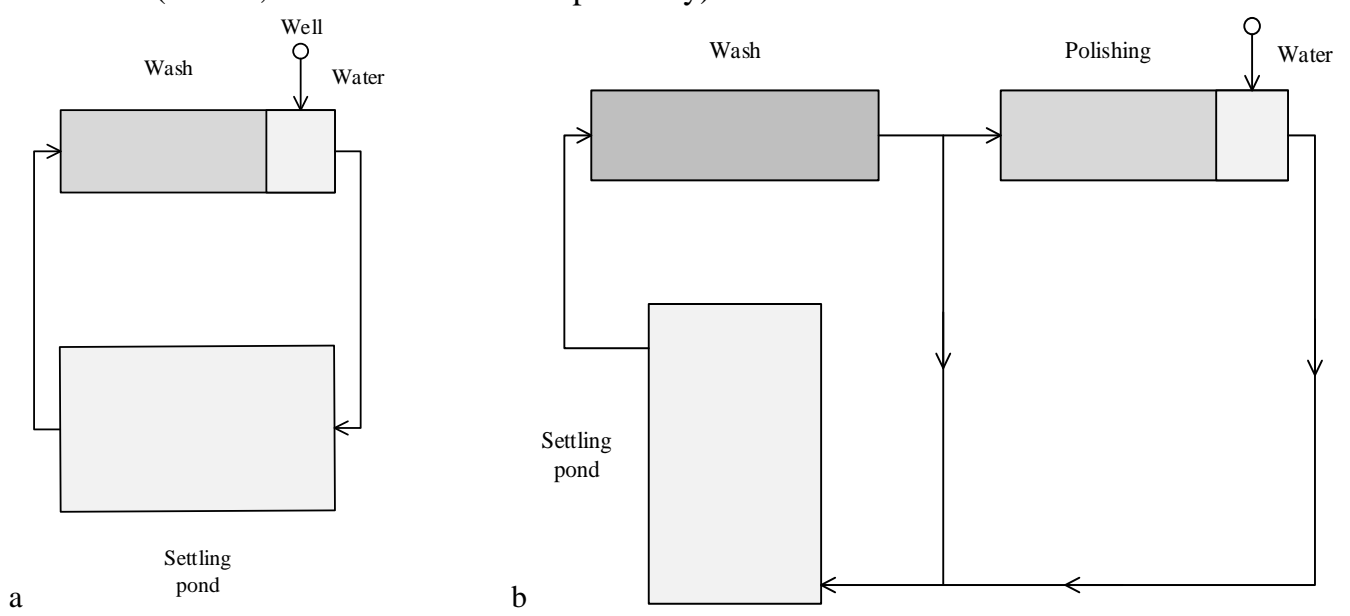

Figure 2. Principle flowchart of root vegetable washing process: $\mathrm{a}$ - beetroots, $\mathrm{b}$ - carrots

One of the investigated carrots washing farms has the land-based treatment system consisting of surface flow constructed wetland and two biological ponds. There the water from the settling tank is discharged to the pond, then it is supplied to surface flow CW with marsh vegetation, and finally, discharged into the second pond (Fig.3). 

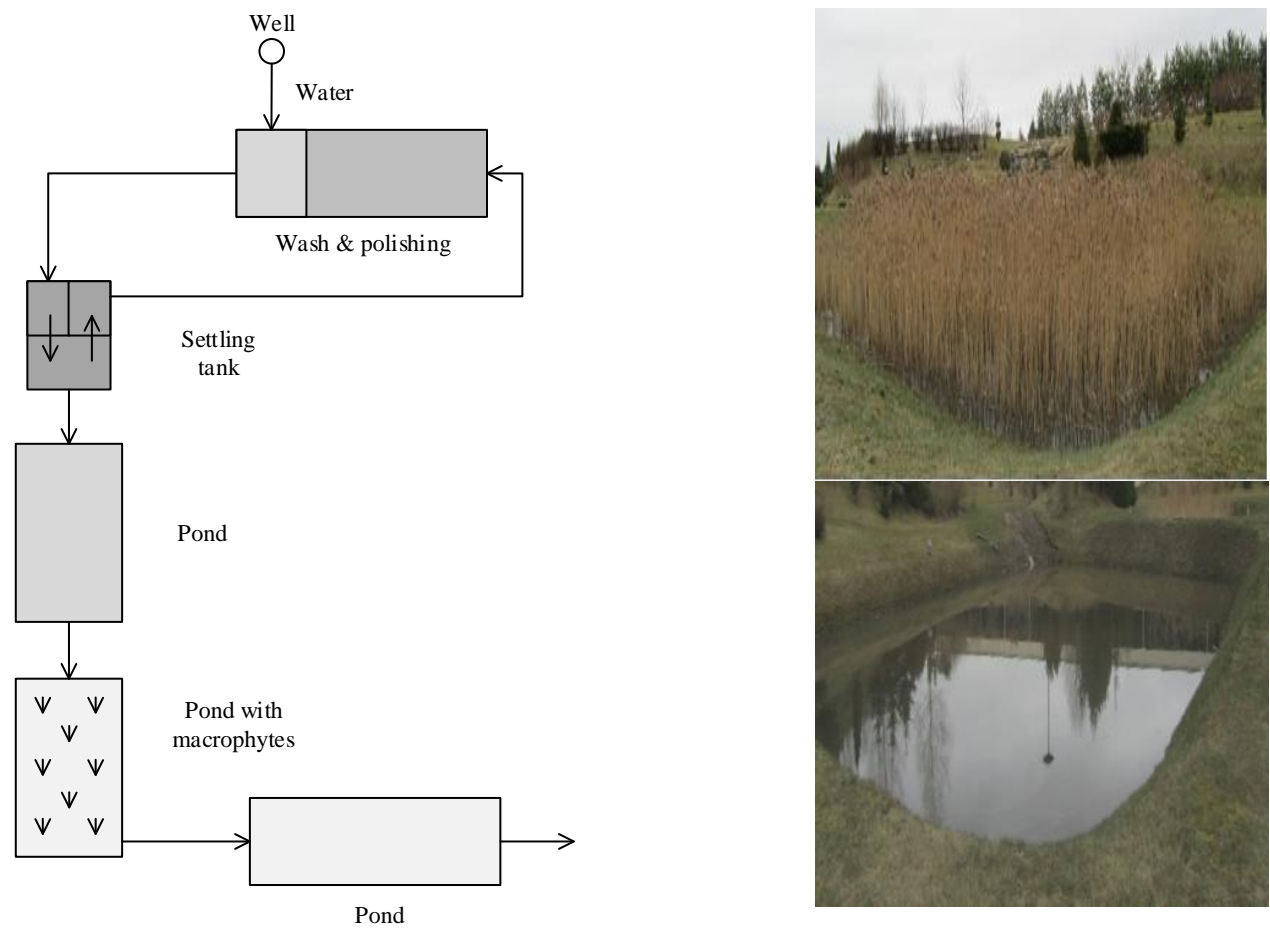

Figure 3. Principle flowchart of the carrot washing and land-based wastewater treatment system consisting of surface flow constructed wetland and biological ponds and their general view

Samples of root vegetable wash water were taken at all stages of the processing activity and wastewater treatment for a total of 12 visits over a one year period. The collected samples were analyzed for water quality parameters.

\section{METHODOLOGY}

Samples of wash water and wastewater were collected monthly according the standartized methodologies in 2016.

Chemical analysis was performed acoording approved methodologies and standards: $\mathrm{BOD}_{7}$ was evaluated according oxygen consumption measured by by oximetric method (ISO 5815-1:2003; ISO 5814:2012), ChDS $\mathrm{Cr}_{-}$by titrimetric oxidimetric method (ISO 6060:2003; ISO 8467:2002); pH and electrical conductivity (EC) - by potentiometric and conductometric methods (ISO 10523:2008; ISO 7888:1985); total P - spectophotometrically at the wavelenght 390 nm) (ISO 7887:2011); Kjelhdal nitrogen - by cathalytic oxidation with analyzer TOC-V, Shimadzu, Japan (EN 1484:1997; ISO 8245:2000; EN 12260:2003, BS 6068-2.83:2003; ASTM D7573 - 09).

Results of the analyses were processed by statistical methods. Contamination of the wash water and wastewater was evaluated comparing the mean values with legislative limit values and with typical sewage contamination values.

Wastewater treatment efficiency was calculated in terms of concentration reductions (Regulation..., 2006):

$$
E=\frac{C_{\text {in }}-C_{\text {out }}}{C_{\text {in }}} \cdot 100 \%
$$

where $C_{\text {in }}$ and $C_{\text {out }}$ were the concentration of a given contaminant in the inflow or outflow sample, $\mathrm{mg} \cdot \mathrm{l}^{-1}$.

\section{RESULTS AND DISCUSSION}

Root vegetables waste water contamination depends on the level of dirt on the washed vegetables, used washing process and waste water treatment scheme. Vegetable wash water is contaminated the most by organic compounds during their processing (polishing, peeling). Vegetable processing wash water BOD makes up of around 90\% of all BOD during vegetable preparation to the market (Mundi et al., 2015). Due to large amounts of organic compounds, it causes not only increase in BOD, but also increase in amounts of phosphorus and nitrogen (Lehto et al., 2014).

Analysis of root vegetable wash water was taken at all stages of the processing activity according to main indices in selected Lithuanian farms. The mean values and range of the carrots and beet root wash water contamination indices at the washing and polishing steps were compared to the typical mean values and legislative limit values (Table 1).

Waste water released to the environment must have neutral or basic $\mathrm{pH}$. Analysed beetroot wash water $\mathrm{pH}$ was neutral ( $\mathrm{pH}$ 6.85-7.64), such waste water can be released to the environment (Regulation..., 2006). Carrot washing and polishing water medium varied from acidic to neutral ( $\mathrm{pH} 4.30$ - 7.77). Acidic waste water must be neutralised before releasing to the environment. 
Table 1. Mean values and range of the carrots and beet root wash water contamination indices at the washing and polishing steps, typical mean values, and limit values

\begin{tabular}{|c|c|c|c|c|c|c|c|c|}
\hline \multirow{2}{*}{ Quality indices } & \multicolumn{2}{|c|}{ Carrots wash water } & \multicolumn{2}{|c|}{ Carrots polishing water } & \multicolumn{2}{|c|}{ Beet root wash water } & \multirow[t]{2}{*}{$\begin{array}{c}\text { Typical } \\
\text { values } 1,2,3\end{array}$} & \multirow[t]{2}{*}{$\begin{array}{c}\text { Limit } \\
\text { values } \\
4,5\end{array}$} \\
\hline & Mean & Range & Mean & Range & Mean & Range & & \\
\hline $\mathrm{pH}$ & 6.04 & $4.30-7.77$ & 5.9 & $4.68-7.12$ & 7.25 & $6.85-7.64$ & 7.5 & $\begin{array}{c}6.5-8.4^{*} \\
6-9 * *\end{array}$ \\
\hline $\begin{array}{l}\text { Electrical conductivity, } \\
\mu \mathrm{S} \cdot \mathrm{cm}^{-1}\end{array}$ & 943.5 & $698-1189$ & 1027 & $530-1524$ & 1009.5 & $805-1214$ & 1000 & $700^{*}$ \\
\hline Suspended solids, $\mathrm{mg} \cdot \mathrm{l}^{-1}$ & 3898 & $196-7600$ & 692.5 & $296-1089$ & 1269 & $88-2450$ & $\begin{array}{c}1475 \\
(850-2100) \\
\end{array}$ & $25 * *$ \\
\hline $\mathrm{BOD}_{7}, \mathrm{mg} \mathrm{O}{ }_{2} \mathrm{l}^{-1}$ & 708 & $297-1119$ & 2368 & $740-3996$ & 279.5 & $179-380$ & $\begin{array}{c}1050 \\
(400-1700) \\
\end{array}$ & $\begin{array}{r}34 * \\
4-6 * * \\
\end{array}$ \\
\hline $\mathrm{COD}_{\mathrm{Cr}}, \mathrm{mg} \cdot \mathrm{l}^{-1}$ & 2509.5 & $393-4626$ & 2125 & $830-3420$ & 458.5 & $178-739$ & $\begin{array}{c}3275 \\
(650-5900)\end{array}$ & $125^{*}$ \\
\hline Total nitrogen, $\mathrm{mg} \cdot \mathrm{l}^{-1}$ & 32.5 & $4-61$ & 13.5 & $2-25$ & 34 & $6.9-61$ & $\begin{array}{l}33.5 \\
(6-61) \\
\end{array}$ & $20^{*}$ \\
\hline Total phosphorus, $\mathrm{mg} \cdot \mathrm{l}^{-1}$ & 9.6 & $0.2-19$ & 1.8 & $0.1-3.5$ & 6 & $1-11$ & $\begin{array}{c}17.5 \\
(6-29) \\
\end{array}$ & $2 *$ \\
\hline
\end{tabular}

*Discharge to the surfase water bodies, ** in surface water bodies

${ }^{1}$ Lehto et al., 2014; ${ }^{2}$ Mundi et al., 2015; ${ }^{3}$ Metcalf, Eddy, 2003.

${ }^{4}$ Regulation on Wastewater Treatment, 2006; ${ }^{5}$ Description of protection requirements for surface water bodies where can live and breed freshwater fish, 2005.

Electrical conductivity (EC) shows total ions concentration in the solution and its salinity. Drinkable and mineral water EC must be up to $2500 \mu \mathrm{S} \cdot \mathrm{cm}^{-1}$ according to Hygiene Norm of Lithuania HN 24:2003 standards (Hygiene..., 2003), and for field watering water - up to $700 \mu \mathrm{S} \cdot \mathrm{cm}^{-1}$ (PSO/FAO, 1985). Analysed root vegetables wash water EC did not exceed HN 24:2003 norms, however, field watering water salinity exceeded PSO/FAO norm. Electric conductivity of waste water increases in large magnitude when salts and acids are used in vegetable processing. Table salt sodium ions have a negative impact on soil quality and destroys clay coloid particles.

Wash water of root vegetables, and particularly of carrots, was highly contaminated by sunken materials. It exceeded regular contamination levels 2.5 times. Lowest sunken materials concentration has been observed in wash water after polishing, because at this stage potable water was being used.

Contamination by easily dividable organic compounds is shown by biochemical oxygen demand BOD. According to $\mathrm{BOD}_{7}$ parameter root vegetables wash waste water are defined as moderately contaminated while carrots polishing waste water - to very contaminated - waste water treatment reglament threshold $\left(34 \mathrm{mg} \cdot \mathrm{l}^{-1}\right)$ was exceeded 70 times. Carrot polishing waste water $\mathrm{BOD}_{7}$ parameter was 3 times larger than wash waste water. This indicated high contamination by organic compounds during washing, what creates good conditions for microorganisms growth. Washing beetroots less small and soluble organic materials are produced because root vegetable peel is not damaged.

Waste water treatment reglament provides boundary $\mathrm{COD}_{\mathrm{Cr}}$ value as $125 \mathrm{mg} \cdot \mathrm{l}^{-1}$ which was exceeded up to 20 times (carrot wash water). COD shows waste waters contamination with all - both easily disolvable and stable organic materials.

Total nitrogen concentration in carrot and beetroot wash water exceeded the boundary value $\left(20 \mathrm{mg} \cdot \mathrm{l}^{-1}\right)$ approximately two times, while total phosphorus $\left(2 \mathrm{mg} \cdot \mathrm{l}^{-1}\right)$ in carrot wash water exceeded the boundary 5 times, beetroot - 3 times (Regulation..., 2006). However, it was determined that only a trace of these elements mineral compounds were present, what suggests that nitrogen and phosphorus are in constitution of organic materials.

The main objective of primary wash water treatment is to remove hard particles and for organic material contaminants a biological treatment is required (Casani, Knøchel, 2002; Lehto et al., 2014).

As it is evidant from the data root vegetables wash water is excessively contaminated by sunken and organic materials, therefore such water cannot be recycled without further treatment and be released to the environment. After carrying out analysis of wash water technologies in Lithuanian vegetable farms, it was determined that extensive treatment methods were used, based on native water treatment methods and systems: settling ponds and tanks, constructed wetlands, biological ponds. The products are finally rewashed with potable quality water.

Efficiency of root vegetables wash water settling and treatment in land-based system was calculated.

Results of settling efficiency of vegetables wash water according to SS, BOD 7 and COD are presented in Fig. 4.

It has been determined that by treating root vegetable waste water in settling ponds, suspended solids were deposided very well. Settling tank SS treatment efficiency was 2-2.5 times smaller due to smaller surface of the container when comparing to ponds (see Fig. 4). $\mathrm{BOD}_{7}$ was treated not with sufficient efficiency, likely because organic materials are dissolved. Beetroot COD treatment efficiency was small because their wash water was dominated by mineral particles since beetroots are not polished or peeled. Phosphorus containing compounds precipitate, therefore a part of it can be removed by settling (20-40\%). 


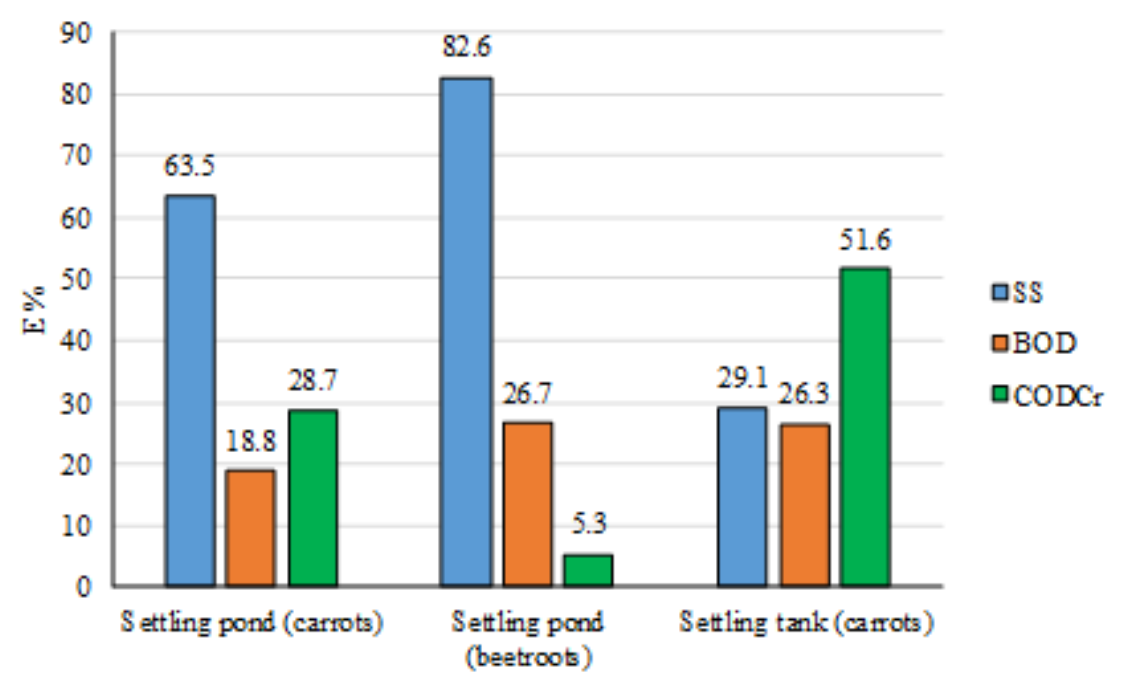

Figure 4. Treatment efficiency of carrots and beetroots wash water in settling ponds and settling tank

Treatment efficiency of carrots washwater in three stages of land-based system - surface flow constructed wetland and two biological ponds according to COD and suspended solids is presented in Figure 5.

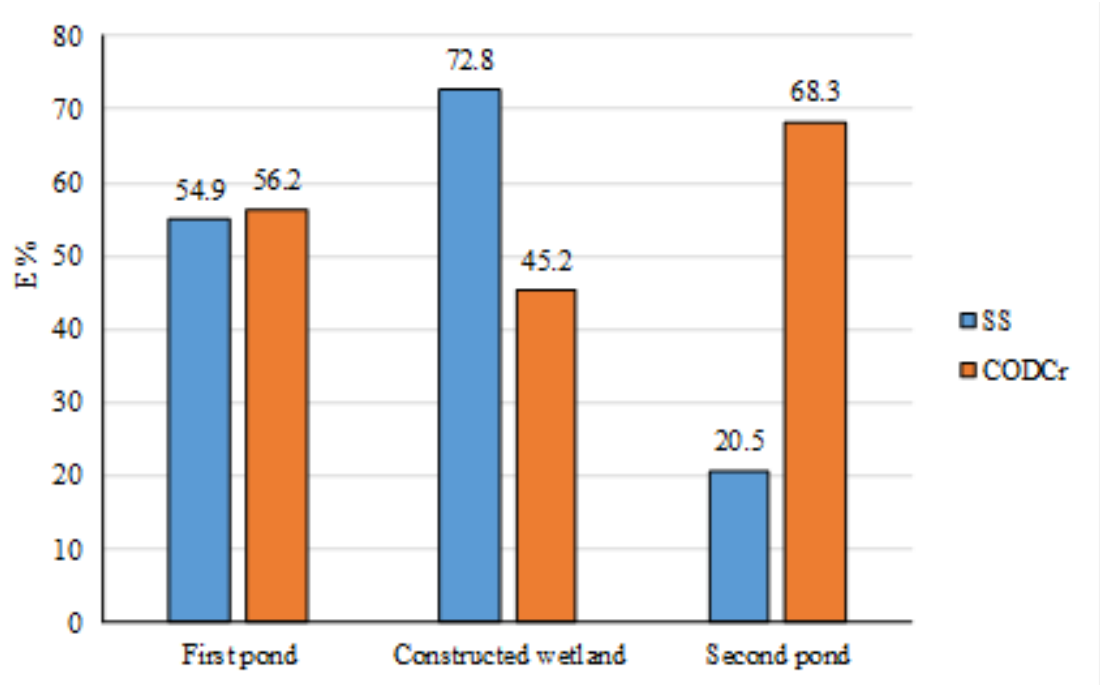

Figure 5. Treatment efficiency of carrots wash water in the surface flow constructed wetland and biological ponds

Total wastewater treatment efficiency of all land-based system (surface flow constructed wetland and two biological ponds) was according to $\mathrm{SS} 90 \%, \mathrm{BOD}_{7}-97 \%, \mathrm{COD}_{\mathrm{Cr}}-92 \%, \mathrm{TN}-98 \%$, TP $-97 \%$. However, the pollution of outlet from the treatment system by suspended solids still was high $\left(333 \mathrm{mg} \cdot 1^{-1}\right)$ and exceeded 13 times the norm equated to natural surface water bodies $\left(25 \mathrm{mg} \cdot \mathrm{l}^{-1}\right)$. Pollution of influent by nitrogen and phosphorus to the land-based system was low (average $\mathrm{TN}-5 \mathrm{mgN} \cdot \mathrm{l}^{-1}, \mathrm{TP}-2 \mathrm{mgP} \cdot \mathrm{l}^{-1}$ ), therefore these materials were fully removed in the system.

Effective wash water treatment in settling tanks and native systems were suggested by other authors. In Canada (Ontario state) a multisectioned potato wash water treatment system was used, containing primary treatment section (settling and aeration) and secondary treatment section (constructed wetlands) (Bosak et al., 2015; 2016). Wash water contamination was: according to $\mathrm{BOD}_{5}-1121$ and $558 \mathrm{mgO} \cdot \mathrm{l}^{-1}, \mathrm{SS}-5234$ and $3600 \mathrm{mg} \cdot \mathrm{l}^{-1}$, TN -222 and $136 \mathrm{mg} \cdot \mathrm{l}^{-1}$, TP -23.4 and $42.6 \mathrm{mg} \cdot \mathrm{l}^{-1}$ accordingly to the first and second year. Due to larger than expected contaminated wash water loads in the first year, treatment system volume was increased from $740 \mathrm{~m}^{3}$ to $1650 \mathrm{~m}^{3}$. Sytem efficiency data was obtained: according to $\mathrm{BOD}_{5}-95$ and $99 \%, \mathrm{SS}-98$ and $99 \%$, TN and TP -77 and $99 \%$, accordingly to the first and second year.

Quality of carrots wash water was studied at the treatment system consisting of the grit chamber, the settling tank and the constructed wetland. On average the efficiency of total COD reduction was $52 \%$ (Kern et al., 2006).

Polish scientists now more than a decade are analysing native systems practical use in vegetable and fruit washing and the recyclability of the wash water. Horizontal and vertical plants ground water filter treatment efficiency was assessed (Soroko, 2003; 2011). Waste water contamination varied from 1500 to $11800 \mathrm{mg} \mathrm{O}_{2} \cdot \mathrm{l}^{-1}$.

Constructed wetlands with the horizontal subsurface flow also showed acceptable quality values of the treated waste water at the output (Soroko, 2003; 2011; Navarro et al., 2013; Puchlik, 2016). Efficiency of the organic matter removal there varied in the range from 34 to $67 \%$ for $\mathrm{BOD}_{5}$ and from 31 to $64 \%$ for $\mathrm{COD}_{\mathrm{Cr}}$ depending on the loading 
rates and composition of the organic substances. The constructed wetland with vertical flow revealed a reduction in the value of the $\mathrm{BOD}_{5}$ in the range from $68.2 \%$ to $86.9 \%$ while $\mathrm{COD}_{\mathrm{Cr}}-$ from $79.3 \%$ to $82.6 \%$, and total $\mathrm{P}$ removal efficiency was $60.2 \%$ (Soroko, 2003; Puchlik, 2016).

There is none constructed wetlands design that is the most effective for agricultural wastewater, but each design has strengths and weaknesses so hybrid designs may prove to be the most practical (Rozema et al., 2016; Strusevičius et al., 2006; Gasiūnas, Strusevičius, 2005).

\section{CONCLUSIONS}

Wash water of carrots is more contaminated as of beetroots due to polishing, wastewater of the vegetables processing is contaminated even more. This causes a larger risk microbiological contamination. For the final root vegetable washing, deep water well water needs to be used and its quality must be within the norms of potable water quality.

Wash water analysis showed that the environment was affected by recirculation systems wastewaters BOD, amount of suspended particles, nitrogen, phosphorus.

Root vegetable wash water are treated with sufficient efficiency by natural methods. Efficiency of the wastewater treatment in the land-based system of surface flow constructed wetland and two biological ponds was according to suspended solids $90 \%, \mathrm{BOD}_{7}-97 \%, \mathrm{COD}_{\mathrm{Cr}}-92 \%$, total nitrogen $-98 \%$, total phosphorus $-97 \%$.

The pollution of outlet from the treatment system by suspended solids still was high and exceeded the norm equated to natural surface water bodies. For treated waste water to be released to the environment, there needs to be an increase in the efficiency of treatment of suspended solids.

Further research of the wastewater treatment efficiency have to be performed in the constructed wetlands and biological ponds as efficient treatment technology of vegetable wash water.

\section{REFERENCES}

1. Alohali, B. 2015. Wash Water Recycling System in Leafy Green Processing, Master Thesis, Canada, pp. 85.

2. Bosak, V., VanderZaag, A., Crolla, A. and Kinsley, C., Gordon, R. 2016a. Performance of a Constructed Wetland and Pretreatment System Receiving Potato Farm Wash Water Water 8, pp.14.

3. Bosak, V.; VanderZaag, A.; Crolla, A.; Kinsley, C.; Gordon.R. 2016b. Integrated Water Resources Management: A case study of on-farm water use for potato processing. Water Practice and Technology, Vol. 11, Iss. 1, pp. 66-74. https://doi.org/10.2166/wpt.2016.008

4. Bosak, V.; VanderZaag, A.; Crolla, A.; Kinsley, C.; Gordon, R. 2015.Treatment of potato farm wastewater with sand filtration. Environmental Technology, Vol. 37, pp.1-8.

5. Casani, S., Knøchel, S. 2002. Application of HACCP to water reuse in the food industry. Food Control, Vol. 13, pp. 315-327. https://doi.org/10.1016/S0956-7135(02)00037-3

6. Description of protection requirements for surface water bodies where can live and breed freshwater fish. 2005. Approved by Order D1-633 of the Minister of Environment (Official Gazette 2006-01-14, No. 5-159) (in Lithuanian)

7. Gasiūnas, V.; Strusevičius, Z. 2005. Efficiency of nitrogen removal in constructed wetlands. Water Management Engineering, Vol. 2, Iss. 5, pp. 50-59.

8. Henze, M., Comeau, Y. 2008. Wastewater Characterization. In: Biological Wastewater Treatment: Principles Modelling and Design. Ed.by M. Henze, M.C.M. van Loosdrecht, G.A. Ekama and D. Brdjanovic. IWA Publishing, London, UK.

9. HMGA Water Project. 2015. Vegetable Washing Process. Available at http://www.hmgawater.ca/blog/vegetable-washing-process (accessed on 06/10/2017)

10. Hygiene Norm of Lithuania HN 24:2003: Safety and quality requirements of drinking-water (Official Gazette, 2003, No. 79-3606; 2007, No. 127-5194)

11. Kern, J., Reimann, W., Schuter, O. 2006. Treatment of Recycled Carrot Washing Water. Environmental Technology 27(4), pp. 459-466. https://doi.org/10.1080/09593332708618656

12. Kirby, R.M., Bartram, J., Carr, R. 2003. Water in food production and processing: quantity and quality concerns. Food Control, Vol. 14, pp. 283-299 https://doi.org/10.1016/S0956-7135(02)00090-7

13. Lehto, M., Sipilä, I., Alakukku, L., Kymäläinen, H-R. 2014. Water consumption and wastewaters in fresh-cut vegetable production. Agricultural and food science, Vol. 23, pp.246-256.

14. Mundi, G., Zytner, R., Warriner, K. 2015. Wash-water Treatment Systems. Presentation of conference Sharing Water Technologies 25.

15. Mebalds, M., Hamilton, A. 2002. Quality wash water for carrots and other vegetables: insurance for clean food and minimising environmental impact.

16. Metcalf, Eddy, Inc. 2003. Wastewater Engineering: Treatment and Reuse. McGraw-Hill Education.

17. Navarro, A. E., Garcia, Y., Vazquez, J., Marrugo, J. L. 2013. Efficiency of a Subsurface Flow Constructed Wetland for Treating Wastewater from Vegetable Packaging. Avances en Ciencias e Ingenieria, Vol. 4(1), pp. 39-50 [In Spanish].

18. PSO/FAO. 1985. Water quality for agriculture. Rome. 
19. Olaimat, AN, Holley, RA. 2012. Factors influencing the microbial safety of fresh produce: a review. Food Microbiology, Vol. 32. Iss. 1, pp. 1-19. https://doi.org/10.1016/j.fm.2012.04.016

20. Olmez, H. 2013. Minimizing water consumption in the fresh-cut processing industry. Stewart Postharvest Review, Vol. 1, pp.1-6. https://doi.org/10.2212/spr.2013.1.5

21. Poach, M.E., Hunt, P.G., Reddy, G.B., Stone, K.C., Johnson, M.H., Grubbs, A. 2004.Swine wastewater treatmentby marsh-pondmarsh constructed wetlands under varying nitrogen loads. Ecological Engineering, Vol. 23, pp. $165-175$. https://doi.org/10.1016/j.ecoleng.2004.09.001

22. Puchlik, M. 2016. Application of Constructed Wetlands for Treatment of Wastewater from Fruit and Vegetable Industry. Journal of Ecological Engineering, Vol. 17, Iss. 1, pp.131-135. https://doi.org/10.12911/22998993/61201

23. Regulation on Wastewater Treatment approved by Order No D1-236 of the Minister of Environment of the Republic of Lithuania of 17 May 2006 (Official Gazette, 2006, No. 59-2103; 2007, No 110-4522) (In Lithuanian)

24. Rozema, E.R. 2016. Vegetable washwater treatment opportunities and outcomes. Proceedings of the 65th Annual Muck Vegetable Growers Conference -APRIL 12-13, 2016

25. Rozema, E.R., VanderZaag, A.C., Wood, J.D., Drizo, A., Zheng, Y., Madani, A., Gordon, R.J. 2016. Constructed Wetlands for Agricultural Wastewater Treatment in Northeastern North America: A Review. Water, Vol. $8, \quad$ Iss. 5. https://doi.org/10.3390/w8050173

26. Soroko, M. 2003. The treatment of wastewater from small fruit and vegetable processing plants in the constructed wetlands. WaterEnvironment-Rural Areas, Vol. 2, No. 8, pp. 119-128. [In Polish].

27. Soroko, M. 2007. Treatment of wastewaters from small fruit and vegetable processing plant in the reed bed systems with vertical flow. Water-Environment-Rural Areas, Vol. 2, Iss. 21, pp. 77-184. [In Polish]

28. Soroko, M. 2011. Annual treatment of wastewater from small fruit and vegetable processing plant in the reed bed system with vertical flow. Water-Environment-Rural Areas, Vol. 1, Iss. 33, pp. 289-298.[In Polish].

29. Stone, K.; Poach, M.; Hunt, P.; Reddy, G. 2004. Marsh-pond-marsh constructed wetland design analysis for swine lagoon wastewater treatment. Ecological Engineering, Vol. 23, pp. 127-133. https://doi.org/10.1016/j.ecoleng.2004.07.008

30. Strusevičius, Z., Gasiūnas, V., Strusevičienė, S.M. 2006. Removal of ammonia and nitrite nitrogen during wastewater treatment in constructed wetlands. Water management engineering, Vol. 30, Iss. 50, pp. 36-43.

31. Wood, J.D.; Gordon, R.J.; Madani, A.; Stratton, G.W.; Bromley, H.M. 2015. Performance of Seasonally and Continuously Loaded Constructed Wetlands Treating Dairy Farm Wastewater. Journal of Environmental Quality, Vol. 44, pp. $1965-1973$. https://doi.org/10.2134/jeq2014.11.0488

32. Zytner, R.G., Warriner, K. 2016 Treatment of Vegetable Wash-water to permit Water Recycling, University of Guelph.

33. VanderZaag, A.C., Gordon, R.J., Burton, D.L., Jamieson, R.C., Stratton, G.W. 2010. Greenhouse gas emissions from surface flow and subsurface flow constructed wetlands treating dairy wastewater. Juournal of Environmental Quality, Vol. 39, pp. 460-471.https://doi.org/10.2134/jeq2009.0166 